\section{acc 384676}

TECHNICAL DIVISION

SAVANNAH RIVER LABORATORY

MEMORANDUM

EP-TOXICITY TEST OF SATURATED GT-73 RESIN AND RESIN IN GROUT
Mercury, EP Toxicity Test, Mercury Loaded Ion, Exchange Resin

DPST $-85-446$

CC: R. Maher, 703-A

D. I. McIntosh, 703-A

E. O. Kiger, 703-A

J. M. McKibben, SF

D. C. Nichols, 773-14A

J. R. Okeson. 773-A

W. R. Stevens, III 773-A

E. I. Albenesius, 773-A

G. W. Wilds, 773-A

M. D. Boersma, 676-T

G. T. Wright, 773-A

R. E. Mersman, 773-A

PMC File, 773-A

SRL Records (4), 773-A

April 24, 1985
TO: M.A.EBRA, 773-A

FROM: J.P.BIBLER, $9 / 2$

SUMMARY

The results of EP-toxicity tests on mercury saturated Duolite GT-73 cation exchange resin clarify options for the ultimate disposal of spent resin.

- Samples of GT-73 saturated with mercury passed the EP-toxicity test, indicating that fully spent resin may be classified as "solid"-not"hazardous"-waste and stored or di sposed of as such.

- Samples of GT-73 resin saturated with mercury and then incorporated into portland Type 1 cement did not pass the Ep-toxicity test and fall into the "hazardous waste" category.

- Samples of GT-73 resin less-than-saturated with mercury which were in corporated in Portland Type I cement passed the EP-toxicity test and may be classified as "solid waste".

- Other commercially available materials are being investigated for incorporating fully spent $\mathrm{GT}-73$ resin in a solid waste form. 


\section{INTRODUCTION}

The chelating cation exchange resin, Duolite ${ }^{\circ} \mathrm{GT}-73$ (formerly ES-465) marketed by Rohm and Haas, has been demonstrated to be extremely effective for removal of mercury from a variety of Savannah River Plant (SRP) waste streams.1-5 However, removal of

the mercury and regeneration of spent resin for reuse requires $3 \mathrm{M}$ $\mathrm{HCl}$ or $2 \mathrm{M}$ SCN-, neither of which is compatible with existing waste streams and would corrode some process vessels. Thus, if the resin is ever used at SRP for mercury removal, it may be prudent to store or dispose of mercury-saturated resin rather than try to regenerate the resin and recoup the mercury. To determine the method of final disposal, the EPA requires a classification test, EP-toxicity, which is used to decide whether the resin should be catagorized as "hazardous" or simply "solid waste". Samples of GT-73 resin loaded to capacity with mercury and the same spent resin incorporated in grout were sent to an independent EPA approved laboratory for the EP-toxicity test.

\section{SAMPLE PREPARATION}

The sodium form of GT-73 cation exchange resin was allowed to come to equilibrum with a saturated solution of mercuric nitrate by shaking a weighed quantity of resin with the solution for two days. After that time, the mixture was filtered and the resin was washed with deionized water, air dried, and reweighed. The process was repeated until the resin reached constant weight, indicating saturation with mercury. [The amount of mercury loaded exceeded the listed capacity of the resin but subsequent experiments in our laboratory have shown that such behavior is possible if a batch mode is used. The published capacity, $1.5 \mathrm{meq} \mathrm{Hg} / \mathrm{mL}$ resin, is valid for column operation.] Some of the dry, spent resin was mixed with water and Portland Type I cement in a laboratory mixer. A blank consisting of the hydrogen form of GT-73 which had no history of mercury exposure was also incorporated in portland Type I cement. Grout samples were poured into a mold $3.15 \mathrm{~cm}$ in diameter and $7.1 \mathrm{~cm}$ tall and allowed to cure for 28 days, after which time all grout and dry resin samples were sent to Envirodyne Engineers of St Louis, Missouri an EPA sanctioned laboratory. Table 1 lists the composition of the samples, including those sent previously by R. E. Mersman. 6

\section{TEST RESULTS}

The EP-toxicity test consists of a physical integrity test and an extraction procedure test. Grout samples were placed in a specially designed compaction tester and a $0.33 \mathrm{~kg}$ weight was dropped 15 times on each sample during the integrity test. None of the samples cracked or broke during the test. The grout samples and the resin samples were then transferred to a stirred extraction vessel 
for leaching. The leachant is distilled water adjusted to a pH of $5.0+0.2$ by the addition of $0.5 \mathrm{~N}$ acetic acid. The sample is leached with $16 \mathrm{~g}$ of leachant per gram of solid sample. During leaching the $\mathrm{pH}$ is maintained at 5.0 by further addition of $0.5 \mathrm{~N}$ acetic acid, with the restriction that no more than $4 \mathrm{~mL}$ of acid per gram of solid may be added. After 24 hours of extraction, the extract is analyzed for specified contaminants. Test results for all samples are reported in Table 1 and in the attached letter from Envirodyne Engineers. In order to be classified as "solid waste" rather than "hazardous", the mercury concentration in the extract cannot exceed $0.2 \mathrm{mg} / \mathrm{L}$. Spent resin not incorporated in grout did not exceed that limit and qualified as "solid waste;" spent resin in grout exceeded that limit and must be classified as "hazardous" as a result of this test.

\section{DISCUSSION OF RESULTS}

Mercury concentrations in the extract from leaching spent resin were ten times below the allowable limit of the EP-toxicity test whereas concentrations from resin in grout far exceeded $0.20 \mathrm{mg} / \mathrm{L}$. Under the conditions of the test, described above, a large concentration of metal ions such as calcium ions will be liberated from the alkaline grout by the action of the acetic acid added to maintain a pH of 5 . These ions will compete with mercuric ions for sites on the resin and, where successful, release mercuric ions into the extract. When the concentration of mercuric ions on the resin is high, as in these tests, the competition is essentially between mercury on the resin and ions solubilized from the grout and only mercuric ions are displaced into the extract. When the concentration of mercuric ions sorbed on the resin is low, as in Mersman's sample (Table 1), competition will displace primarily hydrogen or sodium ions and very few mercuric ions from the resin. Competing metal ions are not available in the samples which contain resin but no grout. There, the hydrogen ion is not concentrated enough to be a successful competitor with mercury for the sulfur groups on the resin and there is no significant exchange between dissolved and sorbed ions. Ultimate disposal, if based solely on the results of the EP-toxicity test, would favor storage or disposal of the spent resin without incorporation into grout. Should incorporation be preferred, however, there are other commercially avai lable materials of incorporation that would not provide the potential source of large quantities of metal ions for competition found in cement.

JPB : pmc

Att

$\# 6$ 


\section{REFERENCES}

1. BIBLER, J. P. and WALLACE, R. M., "Mercury Removal from Dilute Waste Streams," DPST-84-781, 1984.

2. BIBLER, J. P. and WALLACE, R. M., "Mercury Removal from Supernate Using Ion Exchange," DPST-84-849, 1984.

3. BIBLER, J. P. and WALLACE, R. M., "Removal of Mercury From Sludge Using Ion Exchange," DPST-84-926, 1984.

4. BIBLER, J. P., "Ion Exchange Removal of phenylmercuric Ion by ES-465," DPST-84-938, 1984 .

5. BIBLER, J. P., and WALLACE, R. M., "Mercury Removal From offgas Condensates," DPST-84-925, 1984 .

6. MERSMAN, K. E., "EP-TOXicity Testing of Mercury Removal Resin Grout," DPST-84-557, 1984 . 
TABLE 1

EP TOXICITY TESTING ${ }^{a}(\mathrm{mg} / \mathrm{L})$ FOR Hg ON GT-73 RESIN

\begin{tabular}{|c|c|c|c|c|c|c|c|c|}
\hline & & \multicolumn{4}{|c|}{ WASTE COMPOSITION } & \multirow[b]{2}{*}{$\begin{array}{l}\text { Hg ppm } \\
\text { IN LEACHANT }\end{array}$} & \multirow[b]{2}{*}{ ANALYTICAL METHOD } \\
\hline & & SAMPLE & g. GT-73 & g. WATEA & $\begin{array}{l}\text { 9. PORTLAND } \\
\text { TYPE } 1 \text { CEMENT }\end{array}$ & $\begin{array}{l}\text { g. } \mathrm{Hg} O N= \\
\text { RESIN }\end{array}$ & & \\
\hline \multirow{5}{*}{$\begin{array}{l}A \\
E \\
S \\
1 \\
N\end{array}$} & 1 & 1 & 27 & 36 & 37 & 0 & & Atomic Absorption \\
\hline & $N$ & 2 & 26.96 & 36 & 37 & 0.04 & $<0.0002$ & Atomic Absorption \\
\hline & $\begin{array}{l}\mathbf{G} \\
\mathbf{R}\end{array}$ & 3 & 48.0 & 47.6 & 40.5 & 0 & $<0.02$ & ICP \\
\hline & 0 & 4 & 33.1 & 47.6 & 40.5 & 14.9 & 0.42 & ICP \\
\hline & $\mathbf{T}$ & 5 & 33.1 & 47.6 & 40.5 & 14.9 & $\gg 1.0$ & ICP \\
\hline \multirow{2}{*}{$\begin{array}{l}\mathbf{O} \\
\mathbf{L} \\
\mathbf{Y}\end{array}$} & $\begin{array}{l}\mathrm{R} \\
\mathrm{E}\end{array}$ & 6 & -83.3 & 0 & 0 & 16.7 & $<0.02$ & $\mathrm{ICP}$ \\
\hline & $\stackrel{1}{N}$ & 7 & 79.4 & 0 & 0 & 20.6 & $<0.02$ & ICP \\
\hline
\end{tabular}

a The maximum allowable concentration is $0.2 \mathrm{ppm}$. Atomic absorption is more sensitive than ICP for $\mathrm{Hg}$. 
Environmant

SLB.HITTED BY:

Ms. J.P. Bibler

E.I. DuPont de Nemours and Company Savannah River Plant

Building 773-A

Aiken, SC 29808
DATE: October 15, 1984 PROJECT NO. 2028-18000

P.O. AX0667755

D.ATE RECEIVED: JuIy 18,1984

S.A.MPLE ANALYZED: Two resix and Three concrete samples for EP Toxicity Tests. Metals only

.HETHODS L'SED:

EPA Publication Sw-64E, 1980, Sections $T$ and $e$

RESLLTS:

EE: No.

63906

530:-

63205

63903

$630: 0$

Ail results are reported in $\mathrm{mg} / \mathrm{l}$

$\Xi \Xi-455$

$E S-4 E \Xi$

Fg-Form
As

0.32

0.06

0.02

GI-73-Hg Form $1 \quad 0.42$

GT-73-jg Form $2 \gg 1.00$
$<0.02$

$<0.02$

$<0.02$

$<0.02$

$<0.02$ $\underline{\text { Se }}$

$<0.02$

$<0.02$

$<0.02$

$<0.02$

$<0.02$ $\mathrm{cd}$

$c x$

$<0.02$

$<0.02$

$<0.01$

$<0.01$

$<0.01$

$<0.02<0.1$
$<0.02<5.2$
$<0.02<0.2$
$<0.02<0.1$
$<0.02,<0.1$

$<0.02,<0.1$
$\underline{B e}$

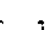

is

$<.2$

- ENVIRODYNE ENGINEERS 